\title{
The Sam D. Carpenter Garden Plot Site (41CP496), Camp County, Texas
}

Timothy K. Perttula

Heritage Research Center, Stephen F. Austin State University

Follow this and additional works at: https://scholarworks.sfasu.edu/ita

Part of the American Material Culture Commons, Archaeological Anthropology Commons, Environmental Studies Commons, Other American Studies Commons, Other Arts and Humanities Commons, Other History of Art, Architecture, and Archaeology Commons, and the United States History Commons

Tell us how this article helped you.

This Article is brought to you for free and open access by the Center for Regional Heritage Research at SFA ScholarWorks. It has been accepted for inclusion in Index of Texas Archaeology: Open Access Gray Literature from the Lone Star State by an authorized editor of SFA ScholarWorks. For more information, please contact cdsscholarworks@sfasu.edu. 


\section{The Sam D. Carpenter Garden Plot Site (41CP496), Camp County, Texas \\ Creative Commons License \\ (c) (1) \& 8}

This work is licensed under a Creative Commons Attribution-NonCommercial 4.0 International License 


\title{
The Sam D. Carpenter Garden Plot Site (41CP496), Camp County, Texas
}

\author{
Timothy K. Perttula
}

\section{INTRODUCTION}

Robert L. Turner, Jr. obtained a surface collection of ancestral Caddo material culture remains from the Sam D. Carpenter Garden Plot site (41CP496) some unknown number of years ago. With records provided by Turner, Bo Nelson has recently recorded the site, and provided the artifacts from the surface collection for analysis.

The site is located in the uplands ( $330 \mathrm{ft}$. amsl) on the west side of the Big Cypress Creek valley, about $2 \mathrm{~km}$ west of the modern channel of Big Cypress Creek (Figure 1). The Sam D. Carpenter Bottom site (4ICP495), another Caddo site, is about $1 \mathrm{~km}$ to the east. Prairie Creek lies several kilometers to the south, while Dry Creek is a comparable distance to the north of the site.

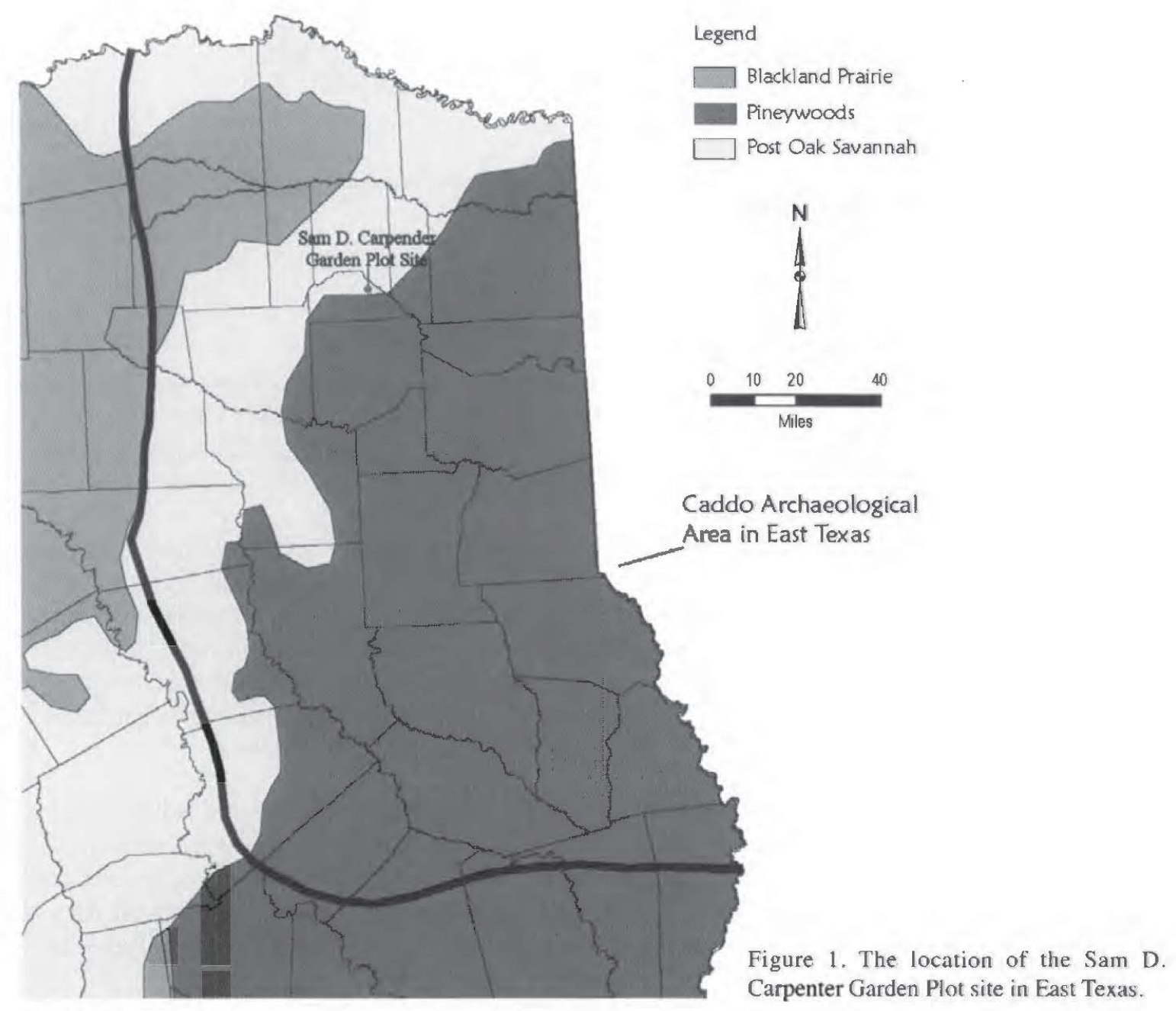




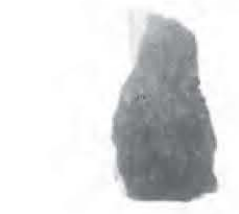

a
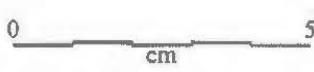
5

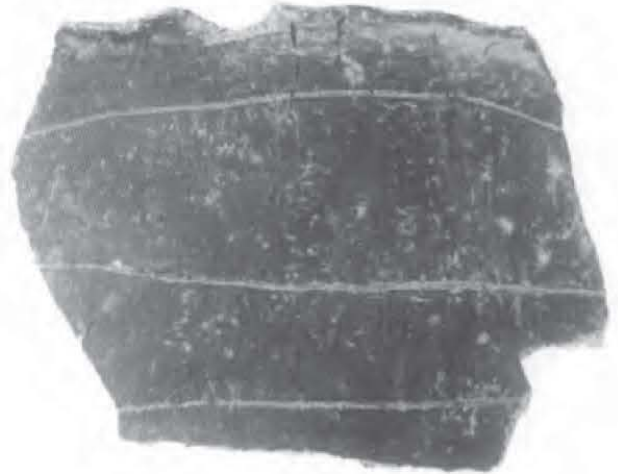

b

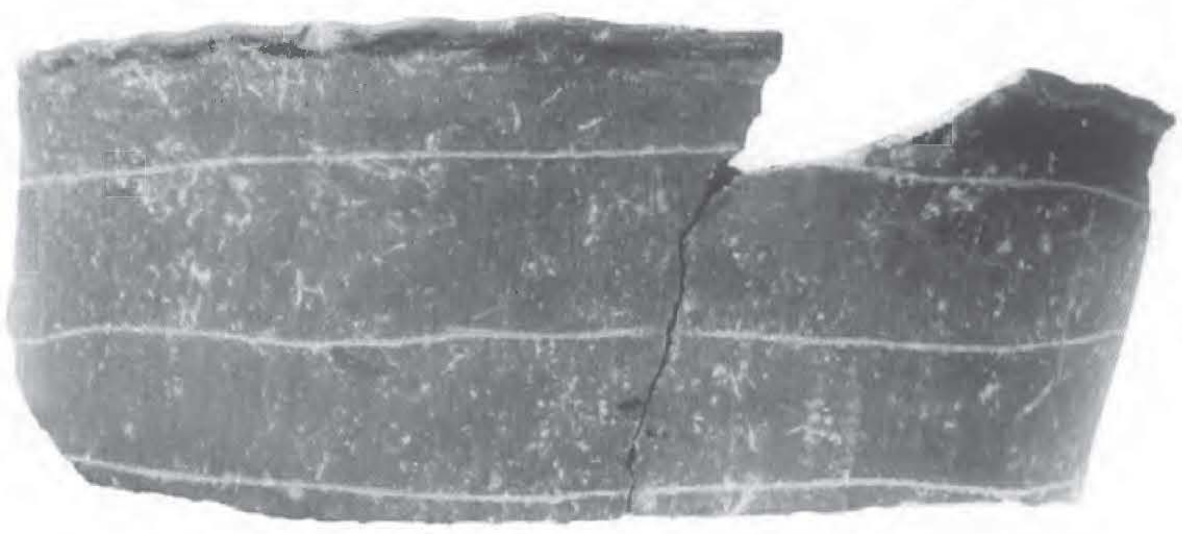

C

Figure 2. Engraved and red-slipped compound bowl sherds from the Sam D. Carpenter Garden Plot site: a, red-slipped rim; b-c, engraved and red-slipped rim sherds.

\section{CERAMIC ARTIFACTS}

The ceramic artifacts in the collection include 83 plain rim, body, and base sherds and 142 decorated utility ware and fine ware rim and body sherds. The plain to decorated sherd ratio is a low 0.58 , consistent with a Late Caddo period site in the Big Cypress Creek basin. The two plain rim sherds have rounded lips and direct or everted rim profiles; one is from a bowl with an orifice diameter of at least $15.0 \mathrm{~cm}$.

The 142 decorated sherds are divided into 47 fine ware sherds (engraved, engraved/red-slipped, and redslipped) and 95 utility ware sherds (wet paste decorations, including brushed, punctated, incised, appliqued, and various combinations of decorative techniques). More than $98 \%$ of the sherds in the assemblage are grog-tempered. There are only two bone-tempered sherds (from red-slipped and engraved vessels), and one shell-tempered sherd in the collection. The shell-tempered sherd may be from a red-slipped Avery Engraved vessel made in the middle Red River valley by McCurtain phase Caddo groups, and traded/exchange with the Titus phase Caddo community living in this part of the Big Cypress Creek basin.

Approximately $26 \%$ of the fine ware sherds (and $8.4 \%$ of all the decorated sherds) in the Sam D. Carpenter Garden Plot site surface collection are red-slipped. This includes one bottle sherd with an exterior red slip and 11 body sherds (one bone-tempered) from carinated bowls and bowls with interior and exterior red-slipped surfaces. Four sherds have engraved elements and interior/exterior red-slipped sherds. One is the previously mentioned shell-tempered vessel body sherd with a single straight engraved line, another 
is a body sherd that has a single horizontal engraved line, and a third has parallel engraved lines. The fourth red-slipped engraved sherd consists of several conjoined rim sherds from a red-slipped and widely-spaced horizontal engraved compound bowl with a direct rim, and a rounded, exterior folded and scalloped lip (Figure 2a-c).

Four of the fine ware sherds ( $8.5 \%$ of the fine ware sherds) are from bottles (Figure 3a-d). These are from Ripley Engraved bottles with curvilinear lines and/or open or hatched pendant triangles. Three of the engraved bottle sherds have a red pigment rubbed in the engraved lines (Figure 3a, c-d).

The remainder of the fine wares $(n=27,57 \%$ of the fine wares and $19 \%$ of all the decorated sherds from the site) are from carinated bowls and compound bowls (Figure 4a-i). The rims are direct in profile, with rounded, exterior folded lips (Figure $4 \mathrm{c}, \mathrm{f}, \mathrm{i})$. The one compound bowl sherd in this group has broadly-spaced horizontal engraved lines on the upper rim panel (Figure 4i).

The carinated bowl rim and body sherds are from Ripley Engraved vessels that have primarily slanting scroll elements (see Figure $4 c, e-f, h)$, and scroll and circle motifs (see Figure 4d), but one sherd may have an interlocking horizontal scroll motif (see Figure 4b). Other elements include hatched, excised, and cross-hatched scroll fill zones and brackets (see Figure $4 a, g$ ), probably also part of unidentifiable scroll motifs. There are no identifiable excised pendant triangles or engraved diamond elements in the Ripley Engraved sherds from the Sam D. Carpenter Garden Plot fine wares.
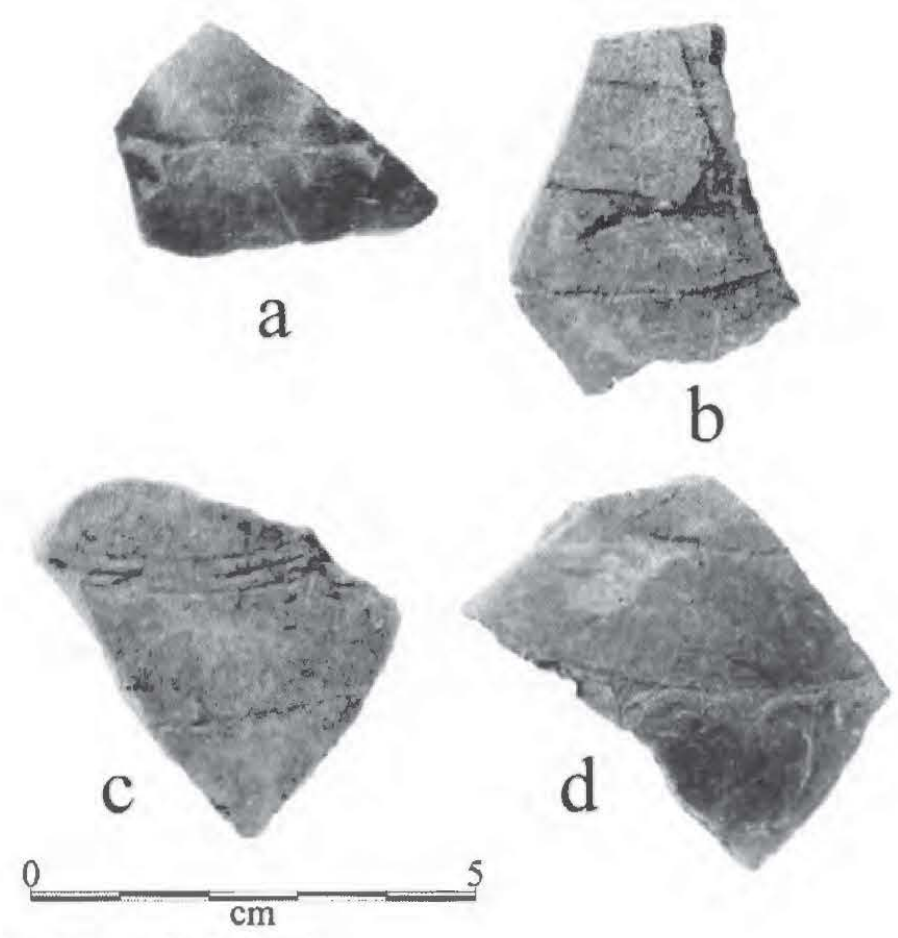

Figure 3. Engraved bottle sherds.
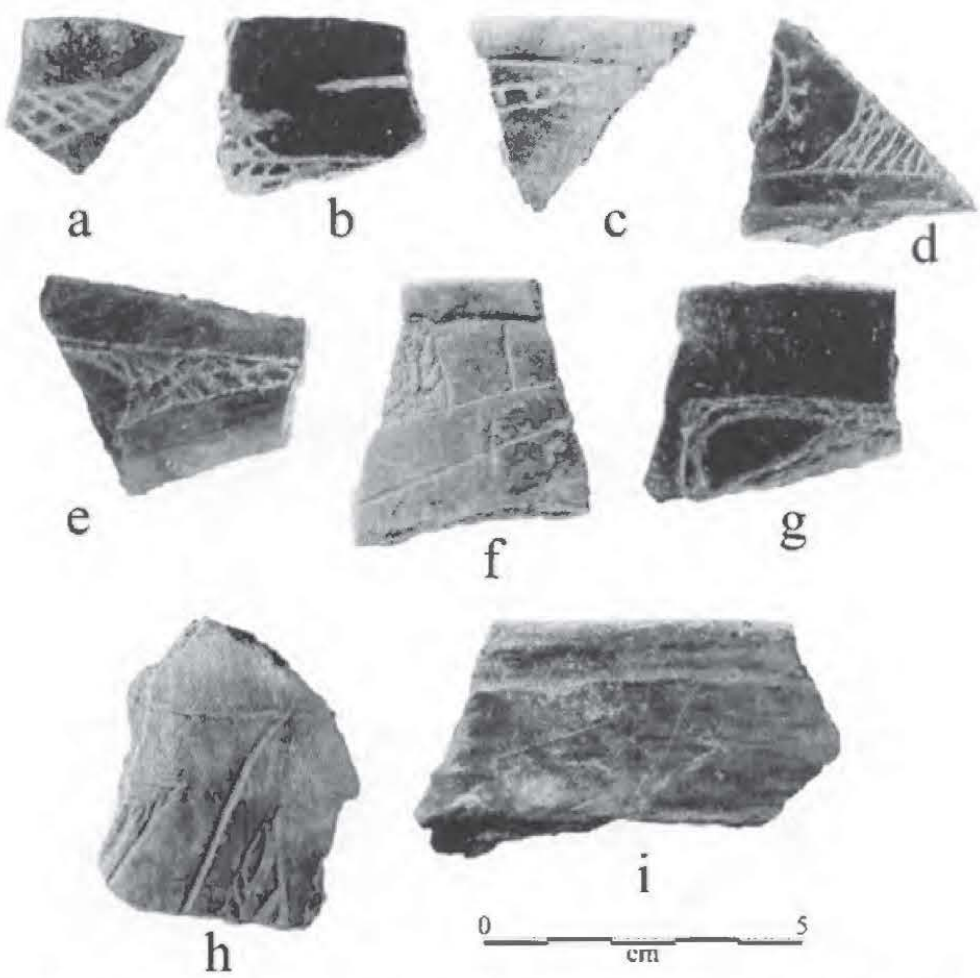

Figure 4. Engraved carinated bowl rim and body sherds: a-h, carinated bowl rim and body sherds; i, compound bowl rim sherd. 
Seven engraved body sherds have a single straight line, and three other body sherds have diagonal opposed engraved lines. Only two (7.4\%) of the non-redslipped engraved sherds and non-bottle sherds have a pigment rubbed in the engraved lines: one sherd with an excised oval has a white pigment (see Figure $4 \mathrm{~g}$ ) and a red pigment on a body sherd with a single straight engraved line.

Two body sherds ( $2 \%$ of the utility wares) are from Harleton Appliqued vessels with curvilinear appliqued fillet elements (Figure 5a). Another body sherd has a curvilinear appliqued fillet and vertical brushing (Figure 5 b), while a second body sherd has a straight ap-

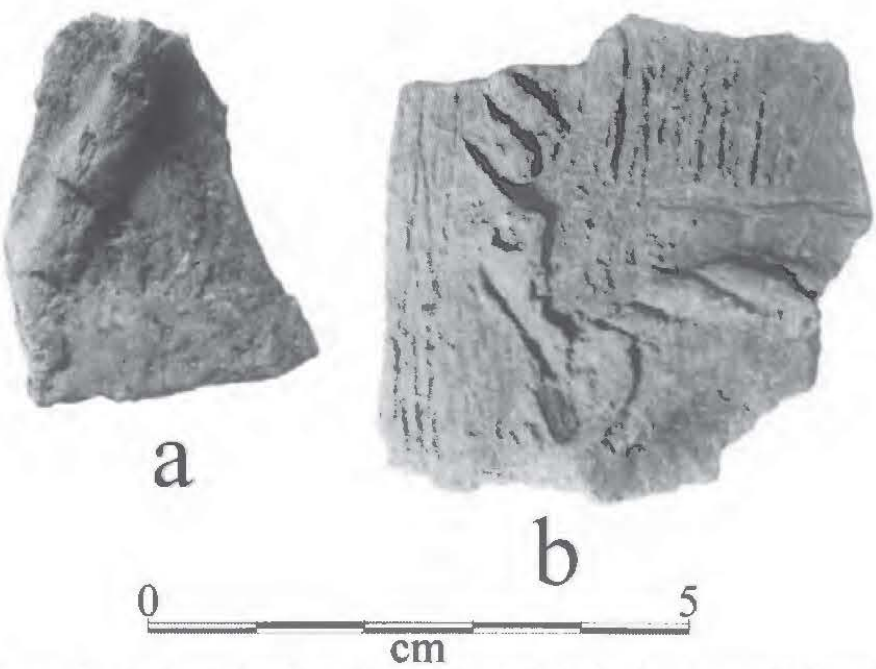

Figure 5. Appliqued and appliqued-brushed body sherds: a, appliqued; b, brushed-appliqued. pliqued fillet and parallel brushing. One body sherd has parallel brushed and incised marks on either side of a straight appliqued fillet. The brushed and appliqued body sherds comprise $3 \%$ of the utility wares.

Sherds with incised decorations are common in the utility wares from the Sam D. Carpenter Garden Plot site ( $26 \%$ of the utility wares and $18 \%$ of all the decorated sherds from the site): there are 23 body sherds (Figure 6a-b, d-e), one lower rim sherd (Figure 6f), and one rim sherd (Figure 6c). The rim sherd has a direct profile and a rounded, exterior thickened lip with horizontal and diagonal incised lines, whilc a lower rim and body sherd from a Maydelle Incised vessel has diagonal opposed incised lines. Four body sherds also have diagonal opposed incised lines (Figure 6b); one body sherd has concentric incised circles (Figure 6a); there are 12 body sherds with parallel incised lines (Figure 6d-e); five body sherds with straight incised lines; and one body sherd with a broad horizontal incised line.

Three utility ware sherds in the collection have incised-punctated decorations ( $3 \%$ of the utility wares). One has tool punctated rows on either side of a straight incised line, and the two others have tool punctated rows on the lower rim and either vertical or diagonal incised lines on the vessel body.

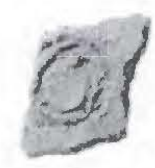

a
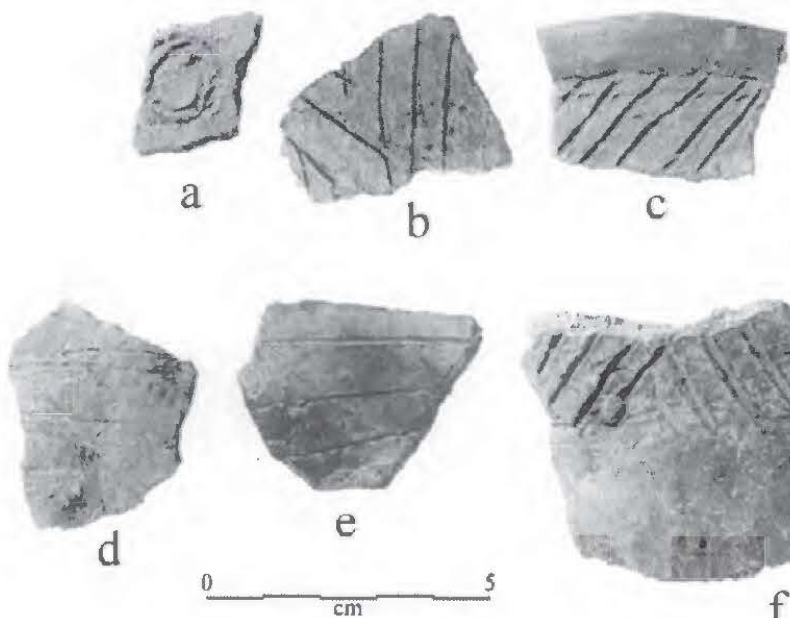

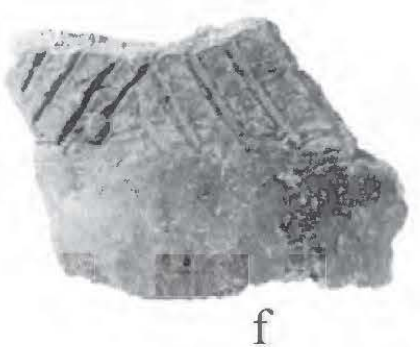

There are eight punctated sherds ( $8 \%$ of the utility wares) in the decorated sherd assemblage from the site. Seven of the eight have tool punctated rows (Figure 7a-c, e-g) on the rim (cf. Mockingbird Punctated jars) and rimbody juncture, while one sherd has a zone of fingernail punctates.

Three sherds $(3 \%$ of the utility wares), including one rim (see Figure 7d), have brushed-punctated decorations. Two rims have horizontal brushing marks as well as a

Figure 6 . Incised rim and body sherds: $a-b, d-e$, body sherds; $c$, rim sherd; $f$, lower rim and body sherd. 


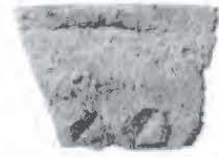

a
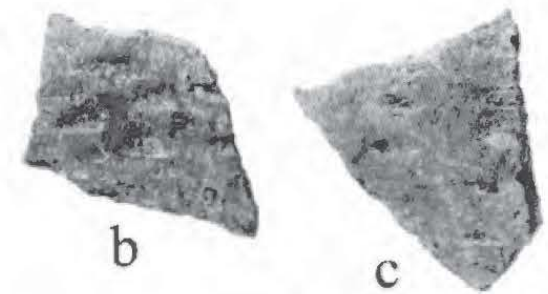

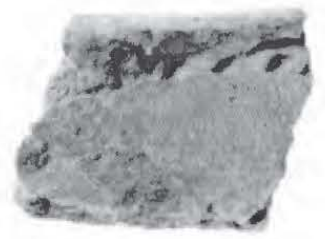

d
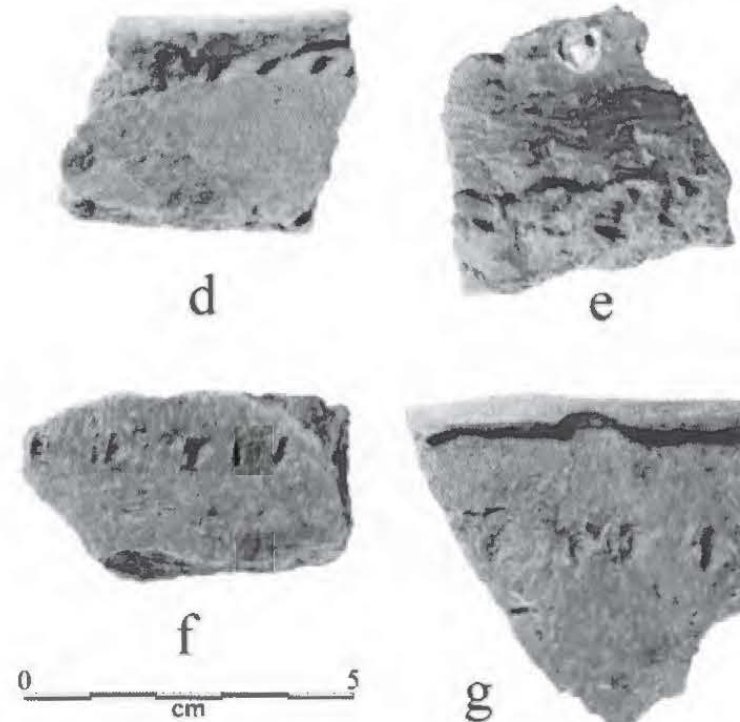

$\mathrm{e}$

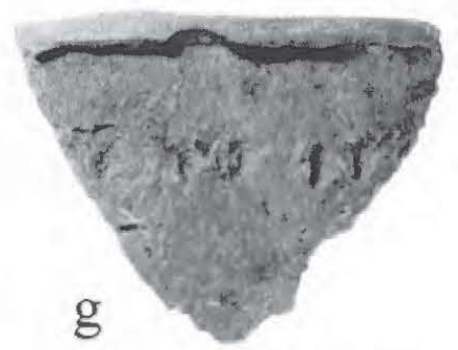

Figure 7. Punctated and punctated-brushed rim and body sherds: a-c, e, g, punctated; d, f, brushed-punctated. row of tool punctations under the vessel lip, while the one lower rim-body sherd has horizontal brushing on the lower rim, and vertical brushing on the body, with a tool punctated row pushed through the brushing (see Figure 7f).

Brushed rim and body sherds $(n=42)$ comprise $44 \%$ of the utility wares from the Sam D. Carpenter Garden Plot site ceramic assemblage, and $30 \%$ of all the decorated sherds from the site. They include an everted rim with horizontal brushing marks (Figure 8a), 39 parallel brushed body sherds (brushing is likely oriented vertically on these jar sherds) (Figure 8b-f), and two body sherds with overlapping brushing marks. These are likely from Bullard Brushed jars, as well as Karnack Brushed-Incised vessels.

Ten body sherds ( $11 \%$ of the utility wares) have brushed and incised decorative elements. Nine have parallel brushedincised lines, while the other has horizon- tal brushing on the lower rim and diagonal brushed-incised lines on the vessel body.

The brushed $(n=42)$, brushed-punctated $(n=3)$, brushed-incised $(n=10)$, brushedappliqued $(n=2)$, and brushedappliqued-incised $(n=1)$ rim and body sherds together comprise $61 \%$ of the utility ware sherds from the site, and $41 \%$ of all the decorated sherds in the assemblage. This high proportion of brushed utility ware sherds may be indicative of the decorated sherd assemblages in eastern Titus phase sites in the Big Cypress Creek basin (Perttula and Sherman 2009:400).

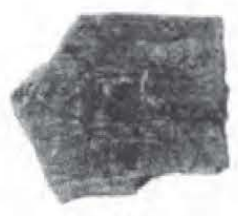

a

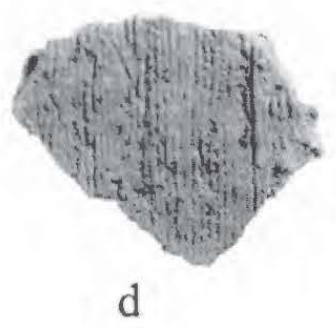

Figure 8 . Brushed rim and body sherds: a, horizontal brushed rim; b-f, parallel brushed body sherds.

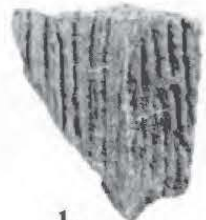

b

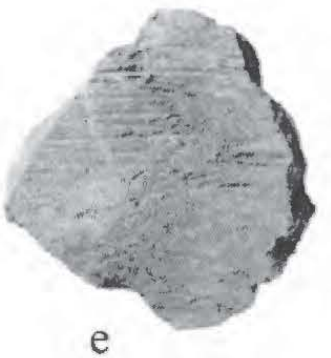

$\mathrm{e}$

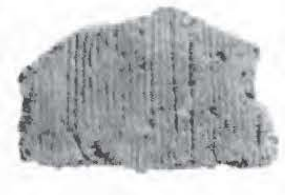

c

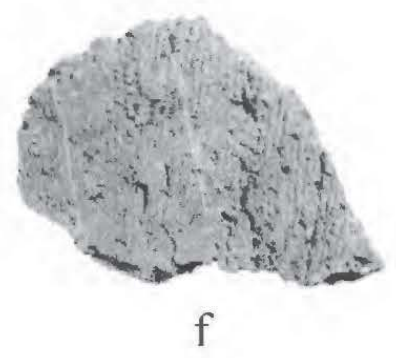




\section{LITHIC ARTIFACTS}

There are two lithic artifacts in the surface collection from the Sam D. Carpenter Farden Plot site. The first is a gray novaculite drill pit fragment, while the other is a piece of flaked hematite/red ochre, probably a fragment of a pigment stone.

\section{MISCELLANEOUS ARTIFACTS}

Miscellaneous artifacts in the surface collection include six pieces of deer bone, five unburned and one burned, one piece of burned turtle bone, as well as a piece of an unburned mussel shell valve. The preservation of these materials on the surface suggests that there are probably buried midden deposits on the site.

\section{CONCLUSIONS}

The Sam D. Carpenter Garden Plot site (4ICP496) appears to be a single component Late Caddo period, Titus phase domestic site located in an upland setting overlonking the Big Cypress Creek valley. A moderate sample of plain and decorated sherds from bowls, carinated bowls, compound bowls, bottles, and jars were collected from the surface of the site by Robert L. Turner, Jr., and they provide an indication of the composition of Titus phase domestic assemblages in the region; the vessels are almost exclusively tempered with grog. Utility wares comprise almost $67 \%$ of the decorated sherds, with the remainder of the decorated sherds from engraved, engraved/red-slipped, and red-slipped fine ware sherds. Plain ware rims indicate that plain vessels are also part of the assemblage.

The utility wares are dominated by jars with brushed bodies and rims (likely from Bullard Brushed and Karnack Brushed-Incised vessels) as well as jars with incised decorations, including diagonal opposed motifs from Maydelle Incised jars. A few sherds are from Harleton Appliqued vessels. The utility wares as a whole more closely resemble eastern Titus phase sites in the Big Cypress Creek heartland (Fields and Gadus 2012:71; Perttula and Sherman 2009) because of the quantities of brushed sherds and the absence of neck banded utility wares. The fine wares, on the other hand, from the Sam D. Carpenter Garden Plot site are more like western Titus phase sites in the Big Cypress Creck heartland because red-slipped sherds are common in the assemblage, and the Ripley Engraved carinated bowl sherds have scroll and scroll and circle motifs, while sherds with pendant triangle elements (i.e., excised pendant triangles and central diamonds) are absent (Perttula and Sherman 2009:400). The absence of Ripley Engraved sherds with the pendant triangle motif also suggests that the site dates sometime prior to ca. A.D. 1600, after which this motif became more prevalent in Titus phase ceramic assemblages (see Perttula 1992:Appendix 1). The one obvious trade ware sherd in the surface-collected assemblage is a shell-tempered, red-slipped engraved body sherd that may be from a Red River McCurtain phase Caddo fine ware vessel.

\section{REFERENCES CITED}

Fields, R. C. and E. F. Gadus

2012 The Pine Tree Mound Site and the Archeology of the Nadaco Caddo. Bulletin of the Texas Archeological Society 83:23-80.

Perttula, T. K.

1992 "The Caddo Nation": Archaeological and Ethnohistoric Perspectives. University of Texas Press, Austin.

Perttula, T. K. and D. L. Sherman

2009 Data Recovery lnvestigations at the Ear Spool Site (4ITT653), Titus Countv, Texas. Document No. 070205. PBS\&J, Austin. 